Research article

\title{
INVESTIGATION OF THE EFFECTS OF ARTEMISININ ON TESTIS AND KIDNEY INJURY INDUCED BY DOXORUBICIN
}

\author{
TUTUN Hidayet $^{1 *}$, ÖZMEN Özlem², AKTAŞ İbrahim ${ }^{3}$ YALÇIN Alper \\ TÜRK Ahmet ${ }^{4}$
}

${ }^{1}$ Burdur Mehmet Akif Ersoy University, Faculty of Veterinary Medicine, Department of Pharmacology and Toxicology, Burdur - Turkey; ${ }^{2}$ Burdur Mehmet Akif Ersoy University, Faculty of Veterinary Medicine, Department of Pathology, Burdur - Turkey; ${ }^{3}$ Adiyaman University, Vocational School of Health Services, Adıyaman-Turkey; ${ }^{4}$ Adiyaman University, Faculty of Medicine, Departments of Histology, Adiyaman Turkey

(Received 27 February, Accepted 17 May 2019)

\begin{abstract}
Artemisinin, an antimalarial drug, has anticancer activity and possesses protective effects against several tissue injuries. The aim of the present study was to investigate the effects of artemisinin on doxorubicin-induced renal and testicular toxicity in rats. Doxorubicin was administered to rats at a single dose of $10 \mathrm{mg} / \mathrm{kg}$ body weight (b.w.) as a single intraperitoneal injection. Application of artemisinin was by using oral gavage feeding needle for 14 days at different specified doses $(7 \mathrm{mg} / \mathrm{kg}$ and $35 \mathrm{mg} / \mathrm{kg}$ b.w.). At the end of the experiments, kidney and testis samples were collected and used for histopathological and immunohistochemical examinations. At histopathological examination, while hyperemia was the marked finding in kidney and testis of rats treated with doxorubicin only, no evidence of structural abnormalities showed in other groups. Immunohistochemical examination of the testes and kidneys demonstrated significantly increased expression of caspase- $3, \mathrm{TNF}-\alpha, \mathrm{NNOS}$ and NF- $x \mathrm{~B}$ in rats treated with doxorubicin only. Artemisinin decreased the doxorubicin-induced overexpression of NF- $x \mathrm{~B}, \mathrm{iNOS}, \mathrm{TNF} \alpha$ and caspase- 3 in these tissues of rats. Artemisinin can protect the kidney and testis against doxorubicin-induced nephrotoxicity and testotoxicity, probably through a decrease of caspase- $3, \mathrm{TNF}-\alpha$, iNOS and NF- $\alpha \mathrm{B}$ expressions. It may be concluded that artemisinin has a potential for clinical use in the treatment of kidney and testis damage induced by doxorubicin. Further researches are required to determine the appropriate combination of artemisinin with doxorubicin.
\end{abstract}

Keywords: Artemisinin, Doxorubicin, Kidney, Rat, Testis

\section{INTRODUCTION}

Cancer is a major public health problem and the second leading cause of death worldwide. Many chemotherapeutic drugs are used to cure various types of cancer. There are a lot of chemotherapeutic agents used either alone or in combination with each other.

\footnotetext{
*Corresponding author: e-mail: hidayettutun@gmail.com
} 
Among antitumor agents, doxorubicin, classified as an anthracycline antibiotic, is one of the most highly effective agents against a wide variety of malignancies including ovarian, breast and lung [1,2]. Despite major advances, many challenges remain in the treatment of cancer. Certain chemotherapy agents such as doxorubicin and cisplatin can cause serious systematic complications. Similar to the side effects of other antitumor drugs, long-term use of doxorubicin causes cumulative and irreversible cardiotoxicity defined as the most prominent adverse effect [3,4]. The cardiotoxicity may limit its use. The mechanism of doxorubicin-induced toxicity remains unclear and is likely to be multifactorial. Production of reactive oxygen species (ROS) by inhibiting redox cycling and topoisomerase II, mitochondrial dysfunction, apoptosis and dysregulation of autophagy are involved [5-7]. In addition to cardiotoxicity, doxorubicin can cause damage in many tissues including liver [8,9], kidney [10], brain [11], lung [12] and testis $[13,14]$.

Natural products like plants have a critical role in the development of medicinal agents. The plants and their active ingredients exert beneficial pharmacological effects such as antibacterial, antitumor, and antioxidant [15-18]. Artemisinin is a sesquiterpene lactone isolated from a plant called sweet wormwood (Artemisia annua L.) which has been used in Chinese herbal medicine as a remedy for malaria and fevers [19]. Several derivatives of artemisinin including artesunate, arteether and artemether have been synthesized in attempts to enhance its effectiveness and utility [20,21]. Artemisinin and its analogs, which are commonly used in the treatment of severe and complicated drug-resistant malaria strains, have also antitumor activity in cell lines [22]. Although artemisinin was first used for malaria, many researches have shown that artemisinin and its derivatives have other beneficial effects such as antitumor [23], antiviral [24], antifungal [25], antiparasitic [26,27], antiinflammatory [28] and antioxidant [29]. The precise mechanism of the biological actions and primary target of artemisinin remains largely ambiguous. It has been reported that an endoperoxide bridge in artemisinin is responsible for its antimalarial and antitumor effects. Artemisinin acts either by inducing DNA damage or by targeting several critical biological pathways including hallmarks of malignancy and leads to cancer cell death [22]. The endoperoxide bridge reacts with free heme [Fe(II)] released during degradation of host hemoglobin by a range of protease enzymes. The breaking of the endoperoxide bridge results in the generation of unstable free radical intermediates such as hydroxyl radicals causing parasite damage. The activity of artemisinin against malaria is probably due to this iron catalyzed formation of free radicals [30]. Also, it has been reported that artemisinin and its derivatives have cardioprotective [31,32] and hepatoprotective [33] effects. Artemisinin may have protective effects against tissue injury induced by different etiologies. Therefore, the objective of the present study was to investigate the effects of artemisinin on doxorubicin-induced renal and testicular toxicity in rats. 


\section{MATERIAL AND METHODS}

\section{Animals}

Male Sprague-Dawley rats ( $\mathrm{n}=49$, age 12-15 weeks; weight 200-220 g) were used in the present study. The rats were provided from Adiyaman University Experimental Animal Unit in Turkey. The rats were acclimatized to laboratory conditions for 7 days before the beginning of the experiments and were housed under a 12-h light-dark cycle at constant temperature $\left(23 \pm 1{ }^{\circ} \mathrm{C}\right)$ and relative humidity of $55-65 \%$. The animals were fed a standard diet and were allowed free access to food and water. The present study was carried out after the approval of the Adiyaman University Animal Experiments Local Ethic Board (2018/011).

\section{Experimental design}

Artemisinin (99\%, J\&K Scientific) and doxorubicin (Doxtu, Onko) were dissolved in sterilized and apyrogenic $\mathrm{NaCI} 0.9 \%$ solution. Application of artemisinin was by means of oral gavage feeding needle for 14 days at different specified doses. Doxorubicin was administered to rats at a single dose of $10 \mathrm{mg} / \mathrm{kg}$ body weight as a single intraperitoneal injection. Forty-nine animals were divided into 7 groups. The first control group (group I) received no treatment. Second control group (group V) was treated with only $\mathrm{NaCI} 0.9 \%(1 \mathrm{ml} / \mathrm{kg})$ orally for 14 days. Group II was treated with only doxorubicin. Group III received doxorubicin and artemisinin (at a dose of 7 $\mathrm{mg} / \mathrm{kg}$ for 14 days). Group IV received doxorubicin and artemisinin (at a dose of 35 $\mathrm{mg} / \mathrm{kg}$ for 14 days). Group VI was treated with only artemisinin at a dose of $7 \mathrm{mg} / \mathrm{kg}$ for 14 days. Group VII was treated with only artemisinin at a dose of $35 \mathrm{mg} / \mathrm{kg}$ for 14 days. At the end of the experiment, kidney and testis samples were taken from each sacrificed rat and fixed in 10\% neutral buffered formalin.

\section{Histopathological examinations}

Formalin fixed tissue samples were routinely processed for histopathological and immunohistochemical examination. For tissue processing automatic tissue processor equipment (Leica ASP300S, Wetzlar, Germany) was used and samples embedded in paraffin wax. Thereon, tissue sections were cut $5 \mu \mathrm{m}$ in thickness by Leica RM2155 rotary microtome (Leica Microsystems, Wetzlar, Germany). Five serial sections were obtained from each block; one was stained with hematoxylin \& eosin (HE), coverslip with a mounting media and examined under a light microscope. Histopathological changes were graded and the remaining four sections were used for immunohistochemistry.

\section{Immunohistochemical examinations}

Sections of $5 \mu \mathrm{m}$ thickness were placed onto polylysine-coated microscope slides. Streptavidinbiotin immunoenzymatic antigen detection system (EXPOSE Mouse and 
Rabbit Specific HRP/DAB Detection IHC kit (ab80436), (Abcam, Cambridge, UK)) was used as a second antibody. Tissue samples were immunostained with primary antibodies. For immunohistochemistry, kidney and testis samples were immunostained with Caspase-3 [Anti-Caspase-3 antibody ab4051)], iNOS [Anti-iNOS antibody (ab15323), NF- $x$ B [Anti-NF- $x$ B p65 antibody (ab16502)] and TNF- $\alpha$ [Anti-TNF alpha antibody (ab6671)] by streptavidin biotin technique. All primary serums and secondary antibodies were purchased from Abcam (Cambridge, UK) and all primary antibodies used at 1/100 dilution. Primary antibodies were incubated for a period of $60 \mathrm{~min}$, and immunohistochemistry was carried out using biotinylated secondary antibody and streptavidin-alkaline phosphatase conjugate. The secondary antibody was used according to manufacturer's instructions. For negative controls the primary antiserum step was omitted. Positive controls were also used for all markers. All examinations were performed on blinded samples. To evaluate the percentage of immune-positive cells for each marker 100 cells were counted in 10 different fields for every section at a magnification under X40 for all groups. Statistical analyses were subjected of the results obtained from the image analyzer. Morphometric analyses were performed using the Database Manual Cell Sens Life Science Imaging Software System (Olympus Co., Tokyo, Japan).

\section{Statistical analysis}

Immunohistochemistry results were analyzed with the SPSS package (version 20.0, USA). The variables were assessed by Bonferroni test and one-way analysis of variance (ANOVA) was used to compare groups. Statistical significance was set at p values $<0.05$.

\section{RESULTS}

Microscopical examination revealed marked hyperemia in the kidneys in group II, while the other groups were normal (Fig.1). Similarly, testes were normal at microscopical examination except in group II, in this group, the testes were hyperemic and edema was also seen in some testes (Fig.2).

At the immunohistochemical examination, a marked increase in caspase- 3 expression in kidneys was observed in group II and artemisinin treatment decreased the expression in group III, negative expression was seen in the other groups (Fig.3). Similarly, a marked expression was detected in testes in group II while no expression was recorded in the other groups (Fig.4).

TNF- $\alpha$ expression in the kidneys between the groups revealed that marked expression was in group II, and a negative expression was recorded for the other groups at immunohistochemical examination (Fig.5). In testes a marked increase in group II was observed while negative expression was observed in the other groups (Fig.6). 


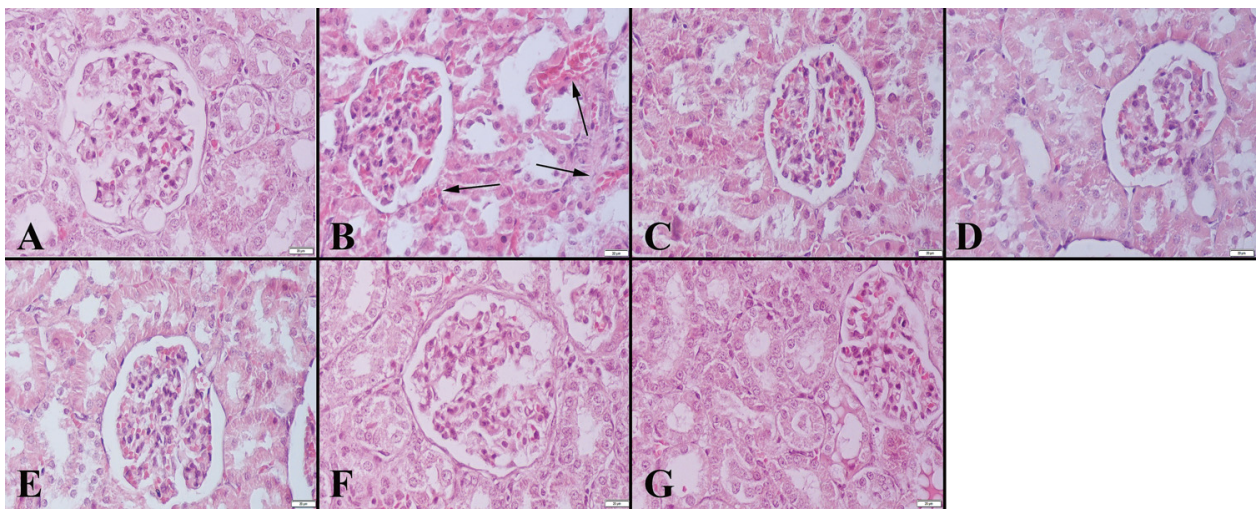

Figure 1. Histopathological appearance of the kidneys between the groups. (A) Normal tissue architecture in Group I, (B) Marked hyperemia (arrows) in Group II, Normal kidney histology in (C) Group III, (D) Group IV, (E) Group V, (F) Group VI and (G) Group VII, HE, Bars= 20 m.

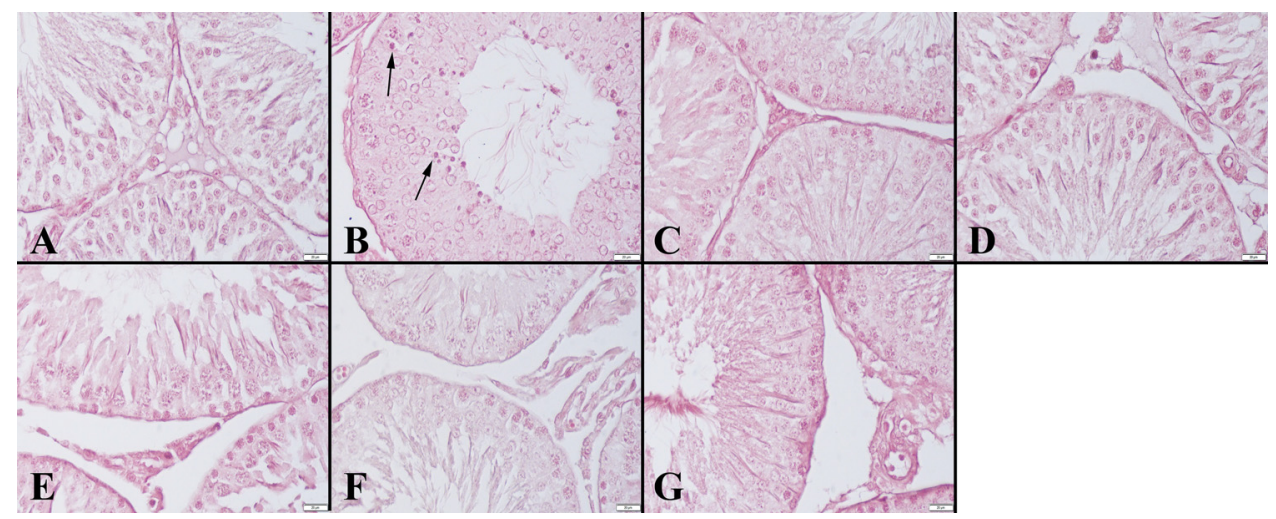

Figure 2. Microscopical appearance of the testes between the groups. (A) Normal tissue architecture in Group I, (B) degenerated cells (arrows) in Group II, Normal testes histology in

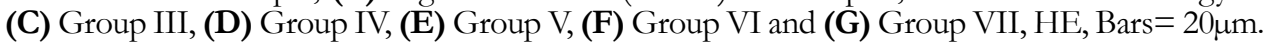

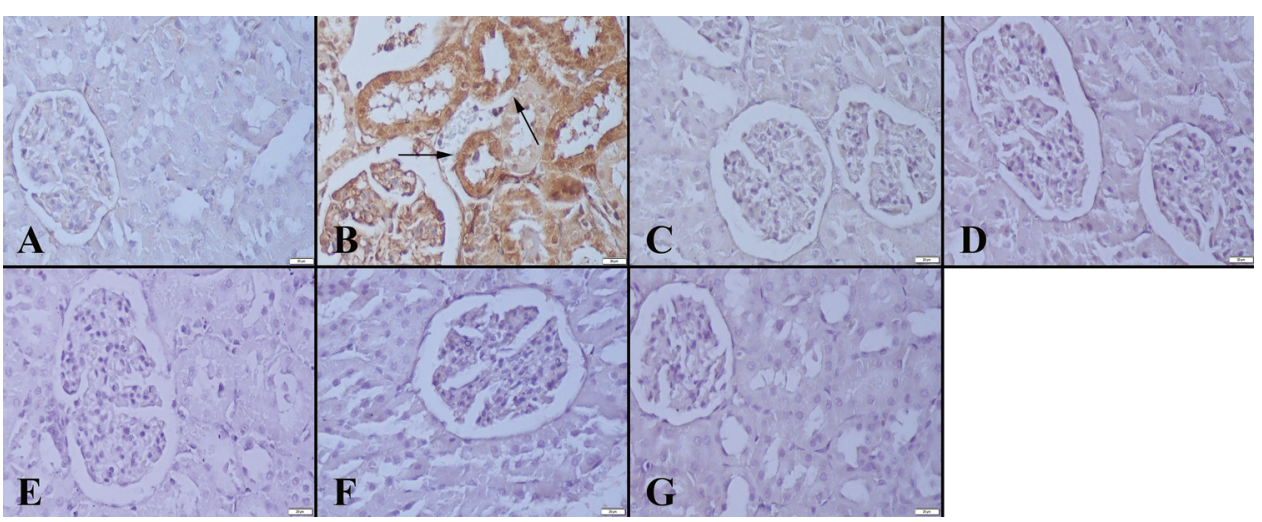

Figure 3. Caspase-3 immunoreaction in kidneys between the groups. (A) Negative immunoreaction in Group I, (B) Marked expression in tubuler cells (arrows) in Group II, (C) negative expression in Group III, (D) Group IV, (E) Group V, (F) Group VI and (G) Group VII, Streptavidin biotin peroxidase method, Bars $=20 \mu \mathrm{m}$. 


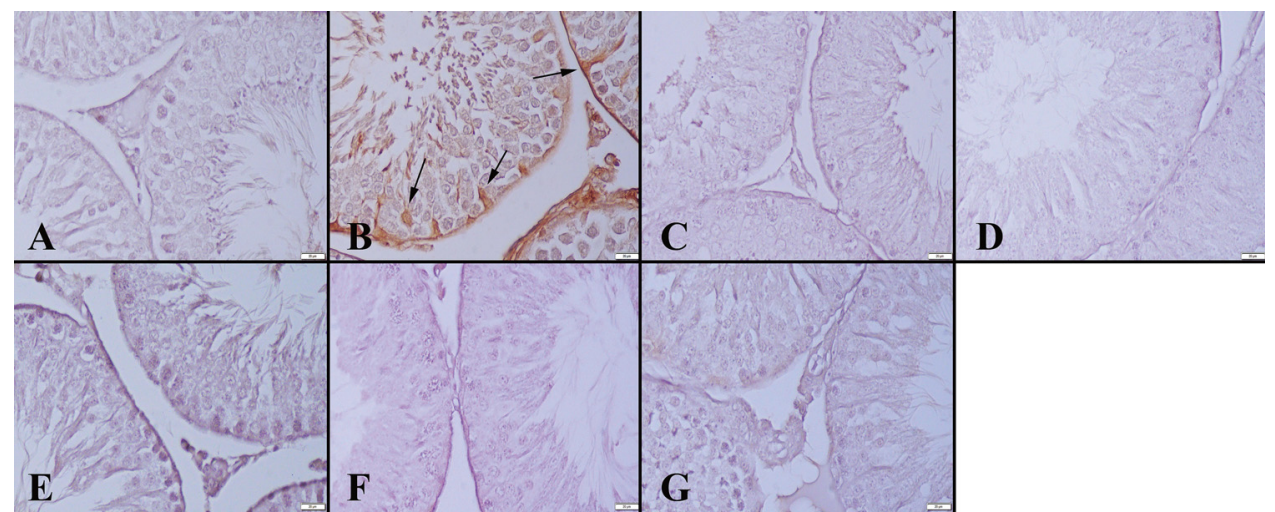

Figure 4. Caspase-3 immunoreaction in testes between the groups. (A) Negative immunoreaction in Group I, (B) Marked expression in Sertoli cells (arrows) in Group II, negative expression in (C) Group III, (D) Group IV, (E) Group V, (F) Group VI and (G) Group VII, Streptavidin biotin peroxidase method, Bars $=20 \mu \mathrm{m}$.

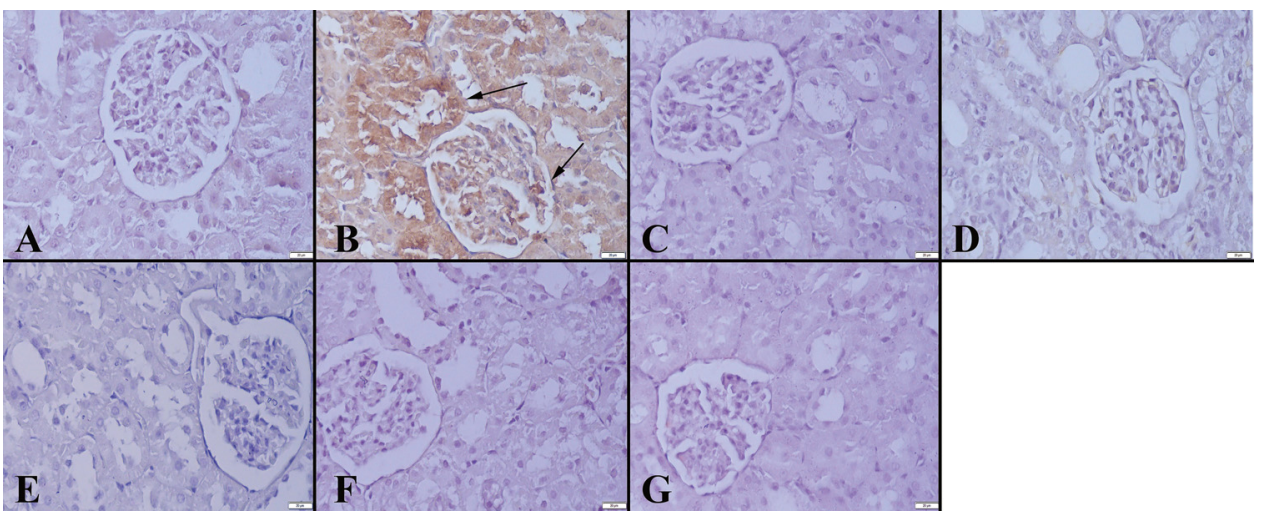

Figure 5. TNF- $\alpha$ immunoreaction in kidneys between the groups. (A) Negative immunoreaction in Group I, (B) Increased expression (arrows) in Group II, negative expression in (C) Group III, (D) Group IV, (E) Group V, (F) Group VI and (G) Group VII, Streptavidin biotin peroxidase method, Bars $=20 \mu \mathrm{m}$.

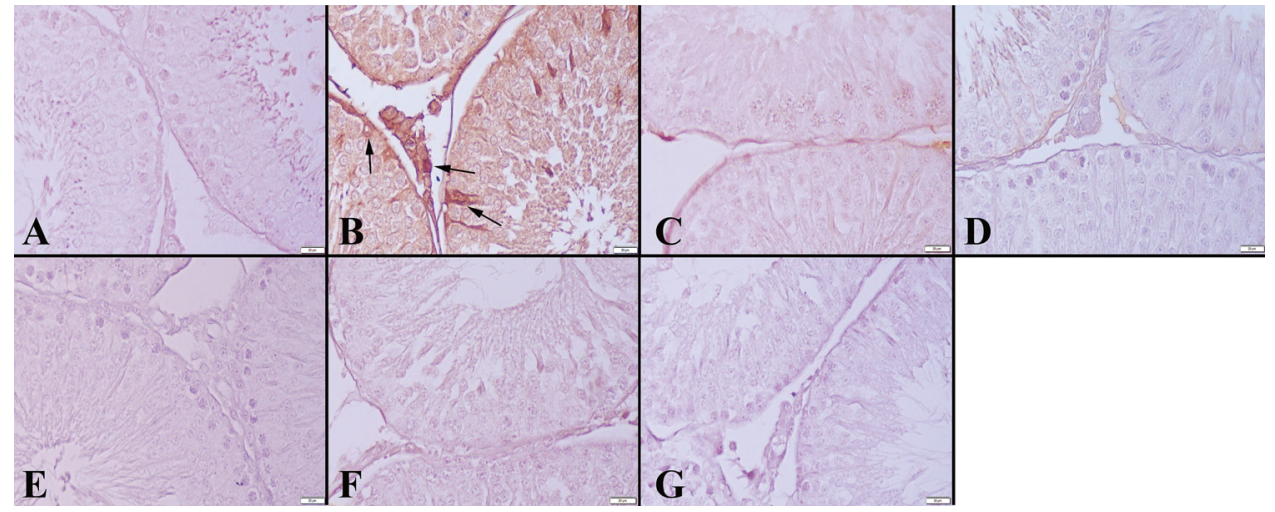

Figure 6. TNF- $\alpha$ immunoreaction in testes between the groups. (A) Negative immunoreaction in Group I, (B) Increased expression in Sertoli and Leydig cells (arrows) in Group II, negative expression in (C) Group III, (D) Group IV, (E) Group V, (F) Group VI and (G) Group VII, Streptavidin biotin peroxidase method, Bars $=20 \mu \mathrm{m}$. 
The immunohistochemical examination of the iNOS expression in kidneys revealed a marked increase in the kidneys in group II, while negative expression was observed in the other groups (Fig. 7). Similarly, a marked increase in group II and decreased immunoexpression were observed in group III, while negative expression was observed in the other groups (Fig.8).

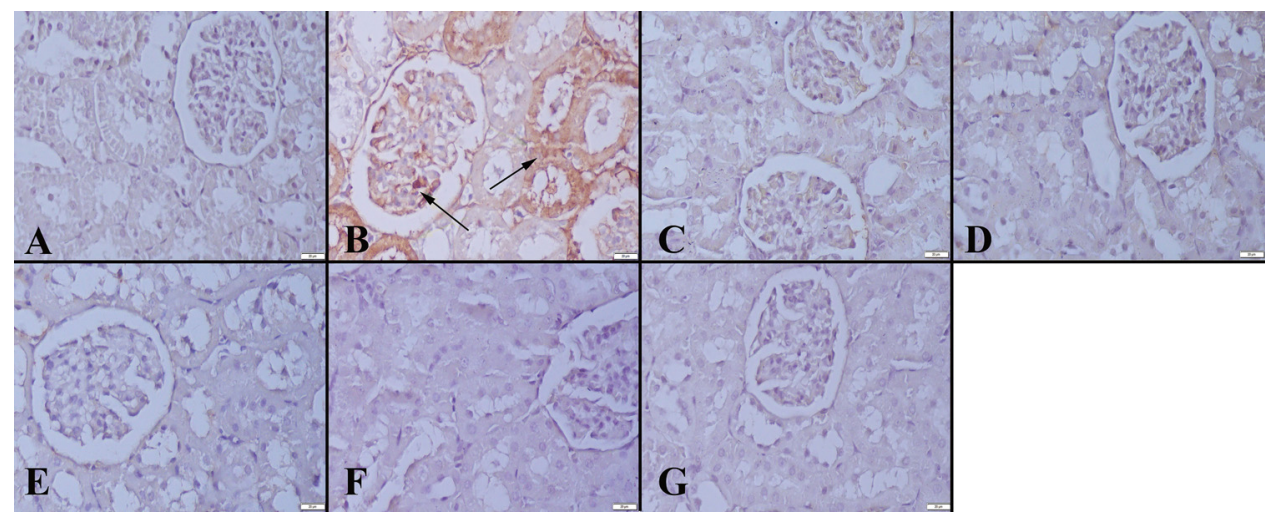

Figure 7. iNOS immunoreaction in kidneys between the groups. (A) Negative immunoreaction in Group I, (B) Increased expression (arrows) in Group II, negative expression in (C) Group III, (D) Group IV, (E) Group V, (F) Group VI and (G) Group VII, Streptavidin biotin peroxidase method, Bars $=20 \mu \mathrm{m}$.

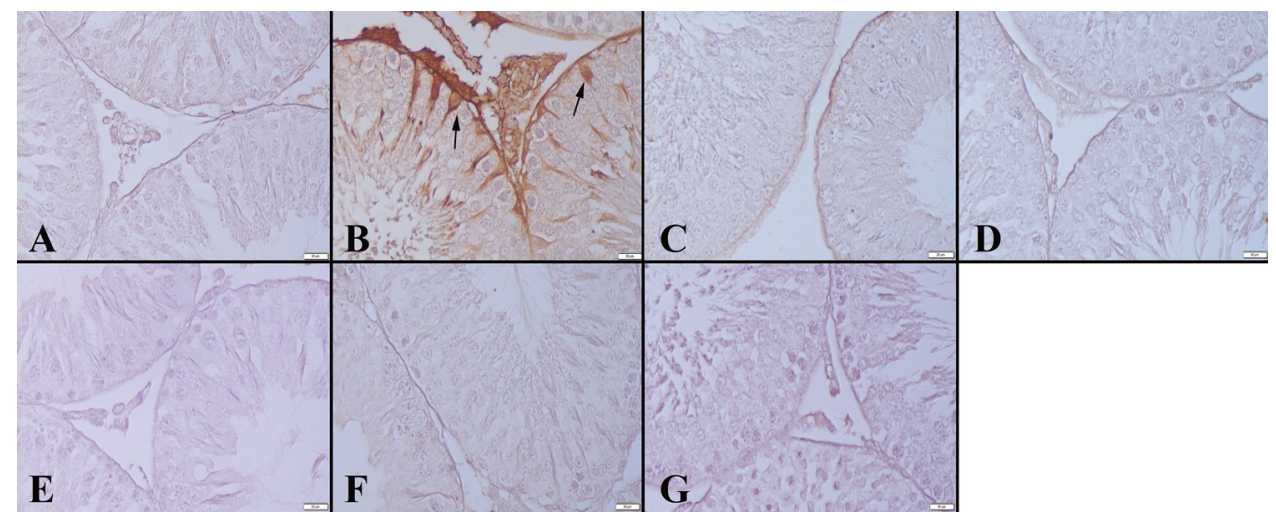

Figure 8. iNOS immunoreaction in testes between the groups. (A) Negative immunoreaction in Group I, (B) Increased expression (arrows) in Group II, negative expression in (C) Group III, (D) Group IV, (E) Group V, (F) Group VI and (G) Group VII, Streptavidin biotin peroxidase method, Bars $=20 \mu \mathrm{m}$.

NF- $x \mathrm{~B}$ immunohistochemistry of the kidneys revealed a marked increase in group II and negative immunoreaction in the other groups (Fig.9). Similarly increase in NFK expression in the testes was also seen and a decreased reaction in group III and negative expression in the other groups were observed (Fig.10). 


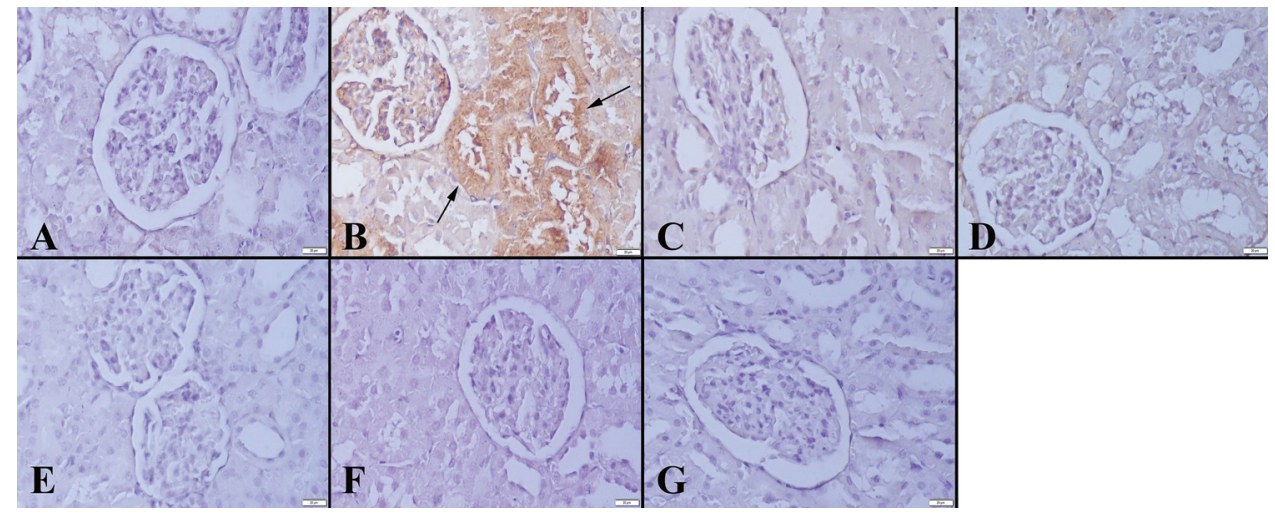

Figure 9. NF- $x$ B immunoreaction in kidneys between the groups. (A) Negative immunoreaction in Group I, (B) Increased expression (arrows) in Group II, negative expression in (C) Group III, (D) Group IV, (E) Group V, (F) Group VI and (G) Group VII, Streptavidin biotin peroxidase method, Bars $=20 \mu \mathrm{m}$.

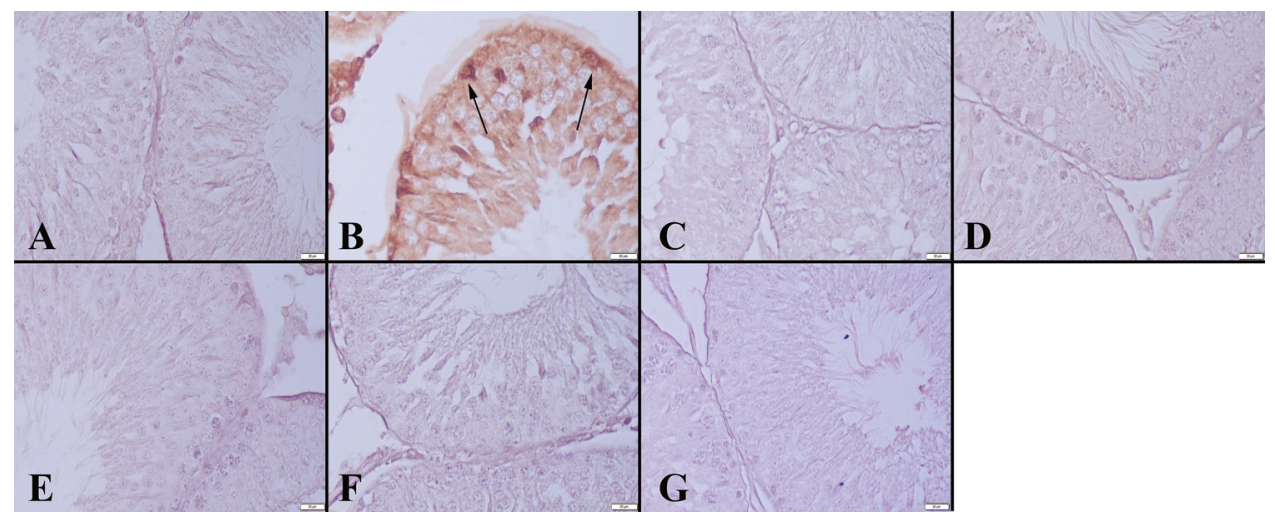

Figure 10. NF- $x \mathrm{~B}$ immunoreaction in testes between the groups. (A) Negative immunoreaction in Group I, (B) Marked expression (arrows) in Group II, negative expression in (C) Group III, (D) Group IV, (E) Group V, (F) Group VI and (G) Group VII, Streptavidin biotin peroxidase method, Bars $=20 \mu \mathrm{m}$.

Doxorubicin caused pathological lesions in the kidney and testes of rats treated with doxorubicin only (group II). Histopathological examination of the kidneys and testes showed no evidence of structural abnormalities in rats of other groups. Alleviation was observed in pathological findings treated with artemisinin by both histopathology and immunohistochemistry. Results were statistically significant between group II and the other groups (Table 1 and 2). 
Table 1. Statistical analysis results of positive cell percentage of kidneys

\begin{tabular}{lcccc}
\hline Groups & Caspase-3 & TNF- $\alpha$ & iNOS & NF- $\boldsymbol{~} \mathbf{B}$ \\
\hline Group I & $1.85 \pm 1.21^{\mathrm{a}}$ & $1.71 \pm 1.11^{\mathrm{a}}$ & $1.85 \pm 0.89^{\mathrm{ab}}$ & $3.71 \pm 0.95^{\mathrm{bc}}$ \\
Group II & $38.14 \pm 6.44^{\mathrm{c}}$ & $29.44 \pm 1.51^{\mathrm{d}}$ & $40.28 \pm 3.72^{\mathrm{d}}$ & $22.00 \pm 4.32^{\mathrm{e}}$ \\
Group III & $5.85 \pm 2.54^{\mathrm{b}}$ & $18.00 \pm 2.94^{\mathrm{c}}$ & $6.28 \pm 1.97^{\mathrm{c}}$ & $8.57 \pm 1.13^{\mathrm{d}}$ \\
\hline Group IV & $2.00 \pm 1.15^{\mathrm{a}}$ & $5.00 \pm 3.10^{\mathrm{b}}$ & $3.85 \pm 1.06^{\mathrm{b}}$ & $4.42 \pm 2.29^{\mathrm{c}}$ \\
Group V & $1.71 \pm 1.38^{\mathrm{a}}$ & $1.85 \pm 0.89^{\mathrm{a}}$ & $2.00 \pm 0.81^{\mathrm{ab}}$ & $2.28 \pm 0.95^{\mathrm{abc}}$ \\
Group VI & $1.71 \pm 1.11^{\mathrm{a}}$ & $1.71 \pm 0.75^{\mathrm{a}}$ & $2.42 \pm 1.13^{\mathrm{ab}}$ & $1.57 \pm 0.97^{\mathrm{ab}}$ \\
Group VII & $0.42 \pm 0.20^{\mathrm{a}}$ & $0.57 \pm 0.20^{\mathrm{a}}$ & $0.57 \pm 0.20^{\mathrm{a}}$ & $0.71 \pm 0.28^{\mathrm{a}}$ \\
\hline
\end{tabular}

Values are expressed as means \pm SD. The relationships between groups and results are assessed by one-way ANOVA, $\mathrm{p}<0.05, \mathrm{p}<0.001$. (a,b,c,d,e) Different characters indicate statistically significant differences in the same column $(\mathrm{p}<0.05, \mathrm{p}<0.001)$

Table 2. Statistical analysis results of positive cell percentage of testis

\begin{tabular}{lcccc}
\hline Groups & Cas-3 & TNF- $\alpha$ & iNOS & NF- $x$ B \\
\hline Group I & $8.00 \pm 1.41^{\mathrm{b}}$ & $8.85 \pm 1.34^{\mathrm{c}}$ & $11.71 \pm 2.28^{\mathrm{c}}$ & $11.14 \pm 1.67^{\mathrm{a}}$ \\
\hline Group II & $74.14 \pm 11.03^{\mathrm{c}}$ & $83.14 \pm 5.84^{\mathrm{e}}$ & $52.57 \pm 3.77^{\mathrm{e}}$ & $48.42 \pm 17.59^{\mathrm{c}}$ \\
\hline Group III & $9.42 \pm 0.97^{\mathrm{b}}$ & $45.42 \pm 4.03^{\mathrm{d}}$ & $18.14 \pm 7.60^{\mathrm{d}}$ & $42.42 \pm 2.14^{\mathrm{c}}$ \\
Group IV & $6.14 \pm 1.21^{\mathrm{ab}}$ & $10.14 \pm 1.06^{\mathrm{c}}$ & $9.00 \pm 0.81^{\mathrm{bc}}$ & $26.28 \pm 9.16^{\mathrm{b}}$ \\
Group V & $4.85 \pm 1.67^{\mathrm{ab}}$ & $8.14 \pm 1.06^{\mathrm{bc}}$ & $8.85 \pm 1.34^{\mathrm{bc}}$ & $9.85 \pm 1.34^{\mathrm{a}}$ \\
\hline Group VI & $4.57 \pm 0.53^{\mathrm{ab}}$ & $5.14 \pm 0.89^{\mathrm{b}}$ & $6.71 \pm 2.05^{\mathrm{b}}$ & $7.57 \pm 0.97^{\mathrm{a}}$ \\
Group VII & $1.28 \pm 1.11^{\mathrm{a}}$ & $1.42 \pm 0.97^{\mathrm{a}}$ & $1.85 \pm 1.46^{\mathrm{a}}$ & $4.14 \pm 2.47^{\mathrm{a}}$ \\
\hline
\end{tabular}

Values are expressed as means \pm SD. The relationships between groups and results are assessed by one-way ANOVA, $\mathrm{p}<0.05, \mathrm{p}<0.001$. $(\mathrm{a}, \mathrm{b}, \mathrm{c}, \mathrm{d}, \mathrm{e})$ Different characters indicate statistically significant differences in the same column $(\mathrm{p}<0.05, \mathrm{p}<0.001)$

\section{DISCUSSION}

Among chemotherapy drugs which are commonly used for tumor, doxorubicin, an anthracycline drug, is a broad spectrum anticancer antibiotic used in treatment of various cancers including both solid and hematological malignancies [1]. However, there are limitations due to its side effects during cancer treatment. Considering the side effects, cardiotoxicity is a well-known side effect related to the peak dose of doxorubicin. The most presumable mechanism of the cardiotoxicity of doxorubicin is associated with creating increased oxidative stress [8,34]. Besides the heart, it accumulates in healthy tissues including the lung, kidney, testis and liver, which result in structural and functional changes in these tissues [12,34,35]. At the histological examination, hyperemia in the kidneys (Fig. 1) and testes (Fig. 2) was observed in group II, while any significant lesions of pathological importance were not exhibited in other groups. Similar findings of nephropathy and testopathy in rats treated with 
doxorubicin only were reported by Srdjenovic et al. [12], Lui et al. [36] and Shivakumar et al. [35]. In the present study, artemisinin alleviated the toxic effect of doxorubicin on testes and kidneys of rats in group III and IV. Also, at the end of the experiments, histopathological examination of the kidneys and testes showed no evidence of structural abnormalities in rats treated with artemisinin only (group VI and VII).

In organisms, both physiological and pathological conditions can trigger apoptosis which is an important physiological process causing cell death as a consequence of specific physiological stimuli and is essential for elimination of potentially harmful cells and maintenance of normal cellular homeostasis [37]. Apoptosis may occur by two main pathways in mammalian cells, the intrinsic (mitochondrial) and extrinsic (death receptors) pathways. These pathways converge on the same terminal pathway initiated by the cleavage of caspase-3, executioner caspase, which is important for maintaining homeostasis via regulating cell death. Activation of caspase-3 leads the controlled demolition of cellular components [38,39]. The extrinsic signaling pathways involve tumor necrosis factor alpha (TNF $\alpha$ ) which is a cell signaling protein secreted mainly by hematopoietic cells and plays an important role in cell differentiation and proliferation, inflammation, immunity, necrosis and apoptosis [40,41]. TNF $\alpha$ activates the nuclear factor-kappa B $(\mathrm{NF}-x \mathrm{~B})$ that is a transcription factor that regulates multiple aspects of innate and adaptive immune functions, cellular growth, necrosis and apoptosis [42-44]. NF- $x \mathrm{~B}$ shows protective activity in apoptosis by activating the expression of antiapoptotic proteins and antioxidant molecules [42]. The activation of $\mathrm{NF}-x \mathrm{~B}$ by $\mathrm{TNF} \alpha$ suppresses apoptosis by induction of $\mathrm{NF}-x \mathrm{~B}$ responsive genes. Also, $\mathrm{TNF} \alpha$ induces expression of inducible nitric oxide synthase (iNOS) through the induction of $\mathrm{NF}-x \mathrm{~B}$ [43]. iNOS is one of the three key enzymes synthesizing nitric oxide (NO) from the amino acid l-arginine. iNOS-derived NO has numerous physiological and pathophysiological roles including wound repair, liver cirrhosis, tumors, neurotransmission, and antiapoptotic effects [45]. Recent results have shown that NO may have anti-apoptotic effects by inhibiting caspase-3 activity [46].

Doxorubicin is toxic to male reproductive organs and spermatozoa by inducing DNA damage and mutations [47]. Doxorubicin-induced toxicity has been attributed to ROS formation promoting necrosis and apoptosis in the kidney and testis tissues of rats $[10,14,48]$. Several studies have reported that expressions of iNOS [10,49], TNF $\alpha[50]$, $\mathrm{NF}-x \mathrm{~B}$ [51] and caspase-3 [52] were increased significantly in doxorubicin induced nephrotoxicity. Also, it has been reported that doxorubicin induced a significant increase in the expression of $\mathrm{TNF} \alpha, \mathrm{NF}-x \mathrm{~B}$, caspase- 3 in the testes of rats $[53,54]$. Similar to previous studies, $\mathrm{TNF} \alpha, \mathrm{NF}-\varkappa \mathrm{B}$, caspase- 3 and iNOS immunoreactivities were found to be significantly high in testes and kidneys of rats treated with doxorubicin only in the present study. Doxorubicin-induced ROS overproduction could enhance the expression of $\mathrm{TNF} \alpha, \mathrm{NF}-x \mathrm{~B}$, caspase- 3 and $\mathrm{iNOS}$ in testes and kidneys in group II. Decreased immunoexpression of $\mathrm{TNF} \alpha, \mathrm{NF}-\varkappa \mathrm{B}$, caspase-3 and iNOS was detected in testes and kidneys of group III and IV compared to group II. Artemisinin and its analogs have shown protective effects against tissue damage 
induced by various etiology [31-33]. In this study, it was observed that artemisinin decreased the toxic effect of doxorubicin on the testis and kidney of rats in group III and IV by decreasing the expression of $\mathrm{TNF} \alpha, \mathrm{NF}-\varkappa \mathrm{B}$, caspase- 3 and $\mathrm{iNOS}$ in these tissues. The antiapoptotic effects of artemisinin supported by Zhoa et al. [33] who reported that artemisinin could inhibit the activation $\mathrm{NF}-x \mathrm{~B}$ and $\mathrm{NOS}$.

A major challenge in the treatment of cancer is to develop an effective drug with high specificity on tumor cells, without damaging normal cells. Natural anticancer products are novel and powerful bioactive compounds with minimal side effects. One of the promising compounds is artemisinin which has significant anticancer activity and protective effects against various tissue damages. The use of artemisinin with anticancer drugs may increase the effect of the anticancer drug on cancer cells and reduce the side effects of the anticancer drug. Results from this study demonstrate that artemisinin can protect the kidney and testis against doxorubicin-induced nephrotoxicity and testotoxicity, probably through its antioxidative function and the decrease of overexpression of $\mathrm{NF}-x \mathrm{~B}, \mathrm{iNOS}, \mathrm{TNF} \alpha$ and caspase- 3 in these tissues. It may be concluded that artemisinin has a potential for the clinical use in treatment of kidney and testis damage induced by doxorubicin. Further researches are required to determine the appropriate combination of artemisinin with doxorubicin.

\section{Acknowledgements}

No financial support was received. The authors declare no conflict of interests.

\section{Authors' contributions}

TH and AI participated in the design of the study and performed animal experimetns and drug applications. OO, YA and TA carried out the immunohistochemistry and histopathology studies. Also, OO performed the statisticial analysis and helped to draft the manuscript. All authors read and approved the final manuscript.

\section{Declaration of conflicting interests}

The author(s) declared no potential conflicts of interest with respect to the research, authorship, and/or publication of this article.

\section{REFERENCES}

1. Olson RD, Mushlin PS, Brenner DE, Fleischer S, Cusack BJ, Chang BK, Boucek RJ: Doxorubicin cardiotoxicity may be caused by its metabolite, doxorubicinol. Proc Natl Acad Sci U S A 1988, 85:3585-3589.

2. Warpe VS, Mali VR, Arulmozhi S, Bodhankar SL, Mahadik KR: Cardioprotective effect of ellagic acid on doxorubicin induced cardiotoxicity in wistar rats. J Acute Med 2015, 5:1-8. 
3. Gorini S, De Angelis A, Berrino L, Malara N, Rosano G, Ferraro E: Chemotherapeutic drugs and mitochondrial dysfunction: Focus on doxorubicin, trastuzumab, and sunitinib. Oxid Med Cell Longev 2018, 7582730

4. Singal PK, Iliskovic N: Doxorubicin-induced cardiomyopathy. N Engl J Med 1998, 339:900905.

5. Childs AC, Phaneuf SL, Dirks AJ, Phillips T, Leeuwenburgh C: Doxorubicin treatment in vivo causes cytochrome $\mathrm{C}$ release and cardiomyocyte apoptosis, as well as increased mitochondrial efficiency, superoxide dismutase activity, and Bcl-2: Bax ratio. Cancer Res 2002, 62:4592-4598.

6. McGowan JV, Chung R, Maulik A, Piotrowska I, Walker JM, Yellon DM: Anthracycline chemotherapy and cardiotoxicity. Cardiovasc Drugs Ther 2017, 31:63-75.

7. Zilinyi R, Czompa A, Czegledi A, Gajtko A, Pituk D, Lekli I, Tosaki A: The cardioprotective effect of metformin in doxorubicin-induced cardiotoxicity: The Role of Autophagy. Molecules 2018, 23:1184.

8. Kalender Y, Yel M, Kalender S: Doxorubicin hepatotoxicity and hepatic free radical metabolism in rats: the effects of vitamin $\mathrm{E}$ and catechin. Toxicology 2005, 209:39-45.

9. Mostafa MG, Mima T, Ohnishi ST, Mori K: S-allylcysteine ameliorates doxorubicin toxicity in the heart and liver in mice. Planta Med 2000, 66:148-151.

10. Ayla S, Seckin I, Tanriverdi G, Cengiz M, Eser M, Soner BC, Oktem G: Doxorubicin induced nephrotoxicity: protective effect of nicotinamide. Int J. Cell Biol 2011, 2011

11. Siswanto S, Arozal W, Juniantito V, Grace A, Agustini FD: The effect of mangiferin against brain damage caused by oxidative stress and inflammation induced by doxorubicin. HAYATI J Biosci 2016, 23:51-55.

12. Srdjenovic B, Milic-Torres V, Grujic N, Stankov K, Djordjevic A, Vasovic V: Antioxidant properties of fullerenol $\mathrm{C} 60(\mathrm{OH}) 24$ in rat kidneys, testes, and lungs treated with doxorubicin. Toxicol Mech Method 2010, 20:298-305.

13. Divya S, Madhuri D, Lakshman M, Reddy AG: Pathological and ultra-structural changes in testis of rats due to doxorubicin toxicity and its amelioration with quercetin. Int. J. Curr. Microbiol. App. Sci 2017, 6:2295-2306.

14. Vapa I, Torres VM, Djordjevic A, Vasovic V, Srdjenovic B, Simic VD, Popović JK: Effect of fullerenol C $60(\mathrm{OH}) 24$ on lipid peroxidation of kidneys, testes and lungs in rats treated with doxorubicine. Eur J Drug Metab Pharmacokinet 2012, 37:301-307.

15. Bilir EK, Tutun H, Sevin S, Kismali G, Yarsan E: Cytotoxic Effects of rhododendron ponticum 1. extract on prostate carcinoma and adenocarcinoma cell line (DU145, PC3). Kafkas Univ Vet Fak Derg 2018, 24:451-457.

16. Keyvan E, Tutun H: Effects of carvacrol on Staphyloccus aureus isolated from bulk tank milk. Med Weter 2019, 75: 238-241.

17. Shin SA, Moon S, Kim WY, Paek SM, Park H, Lee C: Structure-based classification and anti-cancer effects of plant metabolites. Int J Mol Sci 2018, 19: 2651.

18. Tutun H, Koç N, Kart A: Plant essential oils used against some bee diseases. TURJAF 2018, 6:34-45.

19. Liao F: Discovery of artemisinin (qinghaosu). Molecules 2009, 14:5362-5366.

20. Abdin MZ, Alam P: Genetic engineering of artemisinin biosynthesis: prospects to improve its production. Acta Physiol Plant 2015, 37:33.

21. Zyad A, Tilaoui M, Jaafari A, Oukerrou MA, Mouse HA: More insights into the pharmacological effects of artemisinin. Phytother Res 2018, 32:216-229. 
22. Crespo-Ortiz MP, Wei MQ: Antitumor activity of artemisinin and its derivatives: from a well-known antimalarial agent to a potential anticancer drug. J Biomed Biotechnol 2011, 2012:247597

23. Wang XM, Zhang L, Ding GF, Wang QZ: Inhibitory effect of dihydroartemisinin on the growth of human prostate cancer PC-3M cells and its mechanism. Zhonghua Nan Ke Xue 2012, 18:590-594.

24. Chou S, Marousek G, Auerochs S, Stamminger T, Milbradt J, Marschall M: The unique antiviral activity of artesunate is broadly effective against human cytomegaloviruses including therapy-resistant mutants. Antiviral Res 2011, 92:364-368.

25. Gautam P, Upadhyay SK, Hassan W, Madan T, Sirdeshmukh R, Sundaram CS, Gade WN, Basir SF, Singh Y, Sarma PU: Transcriptomic and proteomic profile of Aspergillus fumigatus on exposure to artemisinin. Mycopathologia 2011, 172:331-46

26. Schultz TL, Hencken CP, Woodard LE, Posner GH, Yolken RH, Jones-Brando L, Carruthers VB: A thiazole derivative of artemisinin moderately reduces Toxoplasma gondii cyst burden in infected mice. J Parasitol 2014, 100:516-521.

27. Want MY, Islamuddin M, Chouhan G, Ozbak HA, Hemeg HA, Dasgupta AK, Chattopadhyay AP, Afrin F: Therapeutic efficacy of artemisinin-loaded nanoparticles in experimental visceral leishmaniasis. Colloids Surf B Biointerfaces 2015, 130:215-221.

28. Wang KS, Li J, Wang Z, Mi C, Ma J, Piao LX, Xu GH, Li X, Jin, X: Artemisinin inhibits inflammatory response via regulating NF- $x \mathrm{~B}$ and MAPK signaling pathways. Immunopharmacol Immunotoxicol 2017, 39:28-36.

29. Juteau F, Masotti V, Bessiere JM, Dherbomez M, Viano J: Antibacterial and antioxidant activities of Artemisia annua essential oil. Fitoterapia 2002, 73: 532-535.

30. O'Neill PM, Barton VE, Ward SA. The molecular mechanism of action of artemisinin-the debate continues. Molecules 2010; 15:1705-1721.

31. Gu Y, Wang X, Wang X, Yuan M, Wu G, Hu J, Tang Y, Huang, C: Artemisinin attenuates post-infarct myocardial remodeling by down-regulating the NF- $x$ B pathway. Tohoku J Exp Med 2012, 227:161-170.

32. Sun LH, Li HZ, Han LP, Jiang CM, Zhao YJ, Gao XX, Tian Y, Xu CQ: Effect of artemisinin on ischemia/reperfusion injury of isolated rat myocardium. Zhongguo Zhong Yao Za Zhi 2007, 32:1547-1551.

33. Zhao X, Wang L, Zhang H, Zhang D, Zhang Z, Zhang J: Protective effect of artemisinin on chronic alcohol induced-liver damage in mice. Environ Toxicol Pharmacol 2017, 52:221226.

34. Pugazhendhi A, Edison TNJI, Velmurugan BK, Jacob JA, Karuppusamy I: Toxicity of Doxorubicin (Dox) to different experimental organ systems. Life sci 2018, 200:26-30

35. Shivakumar P, Rani MU, Reddy AG, Anjaneyulu Y: A study on the toxic effects of doxorubicin on the histology of certain organs. Toxicol Int 2012, 19: 241.

36. Lui RC, Laregina MC, Herbold DR, Johnson FE: Testicular cytotoxicity of intravenous doxorubicin in rats. J Urol 1986, 136:940-943.

37. Green DR, Llambi F: Cell death signaling. Cold Spring Harb Perspect Biol 2015, 7; a006080.

38. Elmore S: Apoptosis: A review of programmed cell death. Toxicol Pathol 2007, 35:495516.

39. McIlwain DR, Berger T, Mak TW: Caspase functions in cell death and disease. Cold Spring Harb Perspect Biol 2013, 5:a008656. 
40. Baud V, Karin M: Signal transduction by tumor necrosis factor and its relatives. Trends Cell Biol 2001, 11:372-377.

41. Turner MD, Nedjai B, Hurst T, Pennington DJ: Cytokines and chemokines: at the crossroads of cell signalling and inflammatory disease. Biochim Biophys Acta Mol Cell Res 2014, 1843:2563-2582.

42. Fan Y, Dutta J, Gupta N, Fan G, Gélinas C: Regulation of programmed cell death by NF- $x$ B and its role in tumorigenesis and therapy. In Programmed cell death in cancer progression and therapy. Dordrecht: Springer; 2008, 223-250

43. Hatano E: Tumor necrosis factor signaling in hepatocyte apoptosis. J Gastroenterol Hepatol 2007, 22:S43-S44.

44. Liu T, Zhang L, Joo D, Sun SC: NF- $x$ B signaling in inflammation. Signal Transduct Target Ther 2017, 2:17023.

45. Lechner M, Lirk P, Rieder J: Inducible nitric oxide synthase (iNOS) in tumor biology: the two sides of the same coin. In Seminars in cancer biology Academic Press; 2005, 15:277-289

46. Džoljić E, Grabatinić I, Kostić V: Why is nitric oxide important for our brain? Funct neurol 2015, 30:159.

47. Kang JK, Lee YJ, No KO, Jung EY, Sung JH, Kim YB, Nam SY: Ginseng intestinal metabolite-I (GIM-I) reduces doxorubicin toxicity in the mouse testis. Reprod Toxicol 2002, 16:291-298.

48. Deman A, Ceyssens B, Pauwels M, Zhang J, Houte KV, Verbeelen D, Van den Branden C: Altered antioxidant defence in a mouse adriamycin model of glomerulosclerosis. Nephrol Dial Transpl 2001, 16:147-150.

49. Benzer F, Kandemir FM, Kucukler S, Comaklı S, Caglayan C: Chemoprotective effects of curcumin on doxorubicin-induced nephrotoxicity in wistar rats: by modulating inflammatory cytokines, apoptosis, oxidative stress and oxidative DNA damage. Arch Physiol Biochem 2018, 124:448-457.

50. Heravi NE, Hosseinian S, Yazd ZNE, Shafei MN, Bideskan AE, Shahraki S, Noshahr ZS, Motejadded F, Beheshti F, Mohebbati R, Parhizgar S, Rad AK: Doxorubicin-induced renal inflammation in rats: Protective role of Plantago major. Avicenna J Phytomed 2018, 8:179.

51. Rehman MU, Tahir M, Khan AQ, Khan R, Oday-O-Hamiza, Lateef A, Hassan SK, Rashid S, Ali N, Zeeshan M, Sultana S: D-limonene suppresses doxorubicin-induced oxidative stress and inflammation via repression of COX-2, iNOS, and $\mathrm{NF} x \mathrm{~B}$ in kidneys of Wistar rats. Exp Biol Med 2014, 239:465-476.

52. El-Sheikh AA, Morsy MA, Mahmoud MM, Rifaai RA, Abdelrahman AM: Effect of coenzyme-Q10 on doxorubicin-induced nephrotoxicity in rats. Adv Pharmacol Sci 2012, 2012.

53. Kabel AM: Zinc/alogliptin combination attenuates testicular toxicity induced by doxorubicin in rats: Role of oxidative stress, apoptosis and TGF- $\beta 1 / N F-x \mathrm{~B}$ signaling. Biomed Pharmacother 2018, 97:439-449.

54. Magalhães J, Ascensao A, Padrao AI, Aleixo IM, Santos-Alves E, Rocha-Rodrigues S, Ferreira A, Korrodi-Gregorio L, Vitorino R, Ferreira R, Fardilha M: Can exercise training counteract doxorubicin-induced oxidative damage of testis proteome? Toxicol lett 2017, 280:57-69. 


\title{
ISPITIVANJE EFEKATA ARTEMISININA NA TKIVO TESTISA I BUBREGA OŠTEĆENIH DOKSORUBICINOM
}

\author{
TUTUN Hidayet, ÖZMEN Özlem, AKTAŞ İbrahim, YALÇIN Alper, \\ TÜRK Ahmet
}

Lek protiv malarije, artemisinin poseduje antikancersku aktivnost i protektivni efekat na ozlede nekoliko tkiva. Cilj studije je bio da se ispita efekat artemisinina na ozlede i toksične efekte doksorubicina na bubrege i testise pacova. Doksorubicin je intraperitonealno aplikovan pacovima jednokratno u dozi od $10 \mathrm{mg} / \mathrm{kg}$ telesne mase (tm). Aplikacija artemisinina je bila u vidu jedne oralne doze u trajanju od 14 dana pri čemu su se razlikovale doze: $7 \mathrm{mg} / \mathrm{kg}$ i $35 \mathrm{mg} / \mathrm{kg} \mathrm{tm}$. Na kraju ogleda, uzorci tkiva testisa i bubrega su uzimani u cilju histopatoloških i imunohistohemijskih ispitivanja. Hiperemija testisa i bubrega je bio osnovni nalaz kod pacova koji su primali samo doksorubicin. Histopatološka ispitivanja su pokazala da nije bilo morfoloških promena u drugim oglednim grupama. Imunohistohemijska ispitivanja testisa i bubrega, pokazala su značajnu ekspresiju kaspase-3, TNF- $\alpha$, iNOS i NF- $x$ B kod pacova koji su bili tretirani samo doksorubicinom. Artemisinin je u ovim tkivima, smanjivao doksorubicinom indukovanu prekomernu ekspresiju NF- $x$ B, iNOS, TNF- $\alpha$ kao i kaspase-3. Artemisinin može da zaštiti tkivo bubrega i testisa od nefropatija i testikulopatija izazvanih dokso-

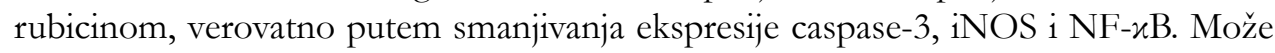
se zaključiti da artemisinin ima potencijalnu kliničku primenu u tretmanu oštećenja bubrega i testisa indukovanih doksorubicinom. Neophodno je da se ispitivanja nastave radi odredivanja odgovarajuće kombinacije artemisinina i doksorubicina. 